This article has been accepted for publication by the Journal Science and Public Policy

It can be cited as follows:

Salvador E., Rolfo S. (2011) "Are incubators and science parks effective for research spin-offs? Evidence from Italy”, Science and Public Policy, vol. 38 (3): 170-184.

\title{
“Are incubators and science parks effective for research spin-offs? Evidence from Italy"
}

\section{By Elisa Salvador and Secondo Rolfo}

\begin{abstract}
In recent years there has been an increasing focus on the research spin-off phenomenon. Spin-off firms are recognised as an important opportunity for universities. Notwithstanding the interest on this field at European and US levels, few are the analyses focused on the Italian case. The goal of this paper is to contribute to the literature on research spin-offs. Original empirical evidence on Italian research spinoffs is provided. More specifically, the attention is focused on the relationship between science parksincubators and spin-offs at regional level. The results of a linear regression model highlight that the higher the number of hosting structures the higher the number of spin-offs. This analysis is completed with the results of a questionnaire investigation: 65 on-park and 90 off-park respondents provided similar answers with few conclusive differences. The debate on the effectiveness of incubators and science parks is still open also in Italy.
\end{abstract}

JEL Codes: O3; L2

Keywords: research spin-offs; science parks; incubators; technology transfer 


\section{Introduction}

In recent years we have assisted to a greater emphasis on the research spin-off phenomenon because these firms can be considered as one of the main tools for the external transmission of knowledge realized in the university. Several analyses and empirical investigations have been published on this field following the great attention paid by several national and regional governments towards the creation and the growth of this kind of firm. Notwithstanding, information on several aspects of the activities of a research spin-off firm is missing and, besides, most of the data are fragmentary (Lockett et al., 2003; Shane, 2004; Lockett, Wright, 2005; Mustar et al., 2006; Gilsing et al., 2010). The focus of this paper is on potential effects available for spin-off firms hosted in a science park or an incubator. To this aim we analyze a large data sample concerning Italian research spin-offs.

Generally in almost all countries the initiatives supporting research spin-offs follow previous policies concerning the creation of an infrastructure specifically devoted to the technology transfer (Rolfo, Calabrese, 2006; Stankiewicz, 1994): during the seventies and eighties the focus was centred around the creation of science and technology parks due to the successful examples in the Anglo-Saxon area; more recently the growing importance of the role of university in the local development (the so-called third mission) has captured the attention of policymakers with a large number of initiatives enhancing the academic entrepreneurship both through the creation of internal structures devoted to technology transfer (liaison offices, incubators), and the creation of new firms issued from academic research.

Italy followed this evolution: after the support devoted to science parks during the eighties, examples of the new focus are given by the Legislative Decree n. 297/1999 concerning spin-off regulations of Italian universities (Salvador, 2009) and by the law 262/2004 regarding the creation of Technology Transfer Offices (TTOs) and Industrial Liaison Offices (ILOs) (Nosella, Grimaldi, 2009). The number of research spin-offs founded in Italy has increased so conspicuously that the importance of the spin-off phenomenon cannot be ignored and an overall investigation was really necessary and desirable. The hypothesis we want to examine in this paper is about the actual benefits that science parks and incubators can bring to spin-off firms, following a large literature concerning the institutional thickness as a source of advantage (Amin and Thrift, 2001). A linear regression model investigates the relationship between the number of hosting structures and the one of spin-offs at regional level and a questionnaire investigation highlights main characteristics as well as main perceptions of on-park and off-park spin-offs. Similar answers and few conclusive differences between the two sub-groups contribute to the debate on the effectiveness of science parks and incubators. Nothwithstanding, the presence of these structures has a positive influence on the one of spin-offs: this characteristic underlines the consciousness of the importance of an infrastructure policy, but, following the suggestions by Kakko and Inkinen (2009), the results of our investigation suggest a strong need for improvement in order to implement and optimize the finding that regions with more science parks-incubators have also more spin-offs.

The paper is structured as follows. Section 1 provides an overview on the definition of a research spinoff and section 2 describes the importance of science parks. Section 3 provides an illustration of the 
methodology applied in the empirical analysis and section 4 describes the regression model which investigates potential relationships between spin-offs and science parks-incubators in all the Italian regions while section 5 illustrates the main results coming from the questionnaires. Finally, section 6 highlights our conclusions.

\section{The identification and the definition of an Italian research spin-off firm}

Following the U.S. long experience in the field of research spin-off firms, also in Europe the phenomenon increased in recent years and it received much attention in the literature (Lockett et al., 2005). Notwithstanding plenty of scientific production on spin-offs, an agreed and a precise definition of research spin-off does not exist. In the economic literature most of the studies on spin-off firms neglect to define precisely the concept of spin-off firm, putting in the same definition different meanings (Pirnay et al., 2003; Degroof, Roberts, 2003 and 2004; Piccaluga, Balderi, 2006; Stankiewicz, 1994). The difference and heterogeneity in spin-off definitions highlights how the spin-off phenomenon is interesting for its own complexity. Trying to underline the significance of this kind of firm, we can say that first of all, according to Schumpeter (1934) research spin-offs can be defined as "innovative firms" if they devote time to research with continuity. Research spin-offs are innovative firms that aim to commercialize research results starting from $R \& D$ and reaching the market and the consumers. It is important to stress the need to develop and improve $R \& D$ activities with continuity, because a spin-off can be defined an innovative firm if it industrializes university research results and if it goes on with research work after the start-up stage. To fully comprehend the innovative firm, there is a need to understand the actual learning processes: the relation between tacit and codified knowledge, between individual and collective capabilities, and between what is learned at a point in time and how that learning cumulates over time. Spin-offs are a typical example of knowledge-based entrepreneurship, with the particularities of scientific knowledge and its mode of transfer (Witt, Zellner, 2007; Hindle, Yencken, 2004). The role as knowledge transfer is clearly central to the innovation process. A known distinction in the knowledge transfer process is drawn between tacit and explicit knowledge (Powell, Grodal, 2005; Bellavista, Sanz, 2009). Spin-offs may be defined as innovative firms which hold tacit knowledge with sometimes a strong base of explicit knowledge.

Second, if we look at the most diffused definitions in the literature, Pirnay et al. (2003) generally define a spin-off firm as a new firm created to develop commercially knowledge, technology, and university research results (Clarysse et al., 2002; Wright et al., 2004; Shane, 2004). In recent years, studies on spin-off firms have adopted a narrow definition of this kind of firm, because of the difficulties involved in trying to identify the number of spin-offs. For example, Wright et al. (2007: 4) define university spin-offs as "new ventures that are dependent upon licensing or assignment of an institution's IP for initiation". The university may own equity in the spin-off in exchange for patent rights it has assigned or in lieu of licence for fees, but this not always happens. The authors justify the choice of a narrow definition on the grounds that this is the one which is most often used in empirical studies, even if not every study includes this specification. These spin-offs are by definition based upon university IP and thus they are the easiest to keep track of for the 
Technology Transfer Office (TTO). Nonetheless, given the reality of some universities in which IP is not necessarily owned by the university and the existence of many companies without formal, codified knowledge embodied in patents, the authors include in their study also "start-ups by faculty based in universities which do not involve formal assignment of the institution's IP but which may draw on the individual's own IP or knowledge" (Wright et al., 2007: 4). They exclude from the analysis only those companies established by graduates. Shane (2004: 4) in the section "the definition of a university spin-off" says "This book defines a university spin-off as a new company founded to exploit a piece of intellectual property created in an academic institution. Companies established by current or former members of a university, which do not commercialize intellectual property created in academic institutions, are not included in the definition of a spin-off employed here."

Given these reflections, we can assume that the main problem is to identify specific criteria in order to define if a firm is a spin-off or not. In our opinion, the focus is on "knowledge": the key difficulty is to evaluate if there has been knowledge transfer from the parent institute to the firm or not. According to this new stream of literature that adopts different and narrow or larger definitions of research spin-off, in this paper we define research spin-off all the firms coming from the research world with or without a university share and a patent, but established by current or former university/research centre members - professors, technical and administraive staff, $\mathrm{PhD}$ candidates - with the aim to exploit research results.

Furthermore, it is difficult to identify and isolate research spin-offs in the larger new technology-based firms ${ }^{1}$ population (Finlombarda, 2006). In Italy, data provided by official national statistics does not supply an exhaustive and reliable description of the research spin-off population at the national and regional level. From these considerations, we can assume that the analysis of the actual research spin-off context in Italy has several methodological difficulties. The phenomenon is relatively recent; as a consequence the data is hard to find. Furthermore, it is still undergoing evolution; it is therefore difficult to estimate the effect of the various support measures on the spin-offs'performance. Last but not least, the phenomenon is difficult to isolate from other characteristics of the context in which it is developed: measures to support spin-offs fall within a larger context of interventions in favour of the creation of high-tech firms and of policies for research and innovation (Finlombarda, 2006). Recently, Zhang (2009) underlined the fact that a paucity of data has always constrained research on university spin-offs. From these considerations, we can assume the importance of the questionnaire results in order to obtain reliable data on this particular kind of firm.

\section{The importance and role of science parks and incubators}

The term "science park" is usually used to describe a property based initiative that has formal and working links with a university or other higher education institution or research centre. A science park is a business support and technology transfer initiative that encourages and supports the start up, incubation and development of innovation led, high growth, knowledge based businesses, provides an environment where larger and international businesses may develop specific and close interactions with a particular centre of knowledge creation for their mutual benefit (Parry, Russell, 2000; Ferguson, Olofsson, 2004). 
The earliest parks were established in North America in the 1950s (Cesaroni, Gambardella, 1999; Colombo, Delmastro, 2002; Sofouli, Vonortas, 2007; Link, Scott, 2003; Wessner, 2009; Bellavista, Sanz, 2009). Silicon Valley with its Stanford Research Park and Route 128 in Massachussets were the first successful initiatives. In Europe, science parks are concentrated in France and the United Kingdom. In Italy the first science parks were established in the 1980s: Area Science Park of Trieste in 1982 and Tecnopolis Novus Ortus of Bari in 1985. Several other examples followed in the coming years due to national (in Southern Italy) and regional initiatives. Since the end of the 1990s, almost every Italian Region has at least a science park (Sancin, 1999). In the absence of an agreed and clear policy, the Italian science parks context is characterized by particularities such that every science park denotes distinctive and almost unique characteristics, not only due to regional needs.

Notwithstanding their dimension and heterogeneity, the rationale for the creation of science parks may be considered proximity to university laboratories and research centres, the presence of an incubator, the creation of networking opportunities, the role of bridging institution providing tenant firms with suitable accommodations and technical and business services (Colombo, Delmastro, 2002; Link, Scott, 2003, 2006, 2007).

Since the 1960s, an incubator ${ }^{2}$ is frequently developed within a science park structure and more and more within a university campus. The incubation process was accelerated by the Internet revolution and its positive feedback on high-tech businesses. Thanking to the ICT revolution and the diffusion of Internet (Benghozi et al., 2009; Borrás, 2003), incubator projects began spreading first in the US and second in Europe. In principle, incubators and science parks alike should be considered as a means to reduce the so called "liability of newness" (Ferguson, Olofsson, 2004; Schwartz, 2009; Sofouli, Vonortas, 2007). Liability of newness relates to the high failure risk young firms face in the first years of their life. Start-ups and young firms do not have stable business relationships and they do not possess any reputation and need some time to gain legitimacy in the market (Schwartz, 2009). Incubators and science parks are perceived as useful solutions: they can work as a network of positive and favourable associations for tenant companies willing to grow. Their function is linked to the necessity to create a stable and effective network of contacts in terms of potential financers, clients, suppliers. Science parks and incubators have a key role to play in the first years of life of newly established companies as the Israeli experience seems to confirm (Pace, 2002). The actual question is whether the potentialities of these structures are translated in concrete effectiveness.

The admission criteria are usually very selective in order to filter good entrepreneurial projects, but the potential success of these business ideas cannot be given for granted. Therefore, the question whether science parks and incubators are really effective in supporting young firms is still without an agreed answer. ${ }^{3}$ Furthermore, according to a recent study by Yang et al. (2009), despite the growing interest in the sciencepark phenomenon, empirical attempts at indentifying whether new technology-based firms located within these structures are more innovative are limited and the results are ambiguous. Schwartz (2009) argued that direct comparisons between survival rates of tenant companies and control-groups of off-park firms may not be meaningful. In fact, the incubator-specific selection process induces relatively low failure rates during 
incubation and thereby selection bias tends to result in an overestimation of the effectiveness of science parks and incubators to this aim. Similarly, Lindelof and Lofsten (2004) asserted that one logical way to assess the technological innovation of science parks is to compare the performance of their tenants to offpark firms. But this approach has its limitations because of the difficulties of identifying a reliable comparison sample.

Given these considerations, in the following analysis we try to contribute to this debate providing the results of a regression model and a questionnaire investigation on Italian research spin-offs. More concretely, we are going to prove the effectiveness of the objectives of science parks and incubators through a questionnaire answers provided directly by spin-off founders and through a comparison between the questionnaire perceptions and characteristics of on-park and off-park spin-offs. This investigation is preceded by a regression analysis with the aim to show whether the number of these structures has an influence on the one of spin-off firms in Italian regions.

\section{The empirical investigation: methodological insights}

The empirical analysis is based on a comprehensive survey of Italian research spin-off firms through face-to-face interviews and a questionnaire, which are also the most used tools of investigation for this kind of firm ${ }^{4}$. The main problem was to identify the actual number of research spin-off firms founded in Italy, because an official, complete and updated list of spin-offs at the regional or national level does not exist. Thus, the first step was to look at ILO, TTO and university websites for a list of spin-offs and the second step was to verify the completeness and updating of this list. Another problem was due to the fact that the university takes care only of spin-offs participated by the university itself. Because of the fact that we decided to adopt a large definition of spin-off including also companies not participated by the university, the university list had to be completed with the Italian science park and incubator tenants list. A final problem was due to the fact that science parks and incubators do not make any difference between spin-offs and startups, which means firms not created by university staff and therefore not linked to the academic world. Telephone and e-mail contact with university staff as well as science park and incubator personnel were pivotal in filling this gap and in excluding start-ups from the final list.

The universe of research spin-off firms ${ }^{5}$ we identified in Italy was 419 . We were able to contact 394 firms: 25 research spin-offs had the positive approval of the university at the time of the survey, but they had not yet been established. This paper is the result of face-to-face interviews carried out between September and October 2007 in some Italian university spin-off firms selected as case-studies and of a questionnaire sent to all the universe of Italian research spin-off firms. The response rate was 39.5\%: 155 spin-offs accepted to answer to the questionnaire. Lack of time and privacy were the most predominant reasons for not participating in the questionnaire investigation: these motivations seem sound considering the inflationary rate of questionnaires received by research spin-offs in recent years (Gupte, 2007). Nevertheless, given the response rate and the geographical distribution of the universe and of the sample (see Figures 2 and 3), we can reasonably consider this sample as representative. 
The questionnaire was sent by e-mail to spin-offs between January and June 2008 with information about the purpose and details of the survey. An e-mail reminder was sent to spin-off firms that did not reply to the first e-mail within a month. The idea of a questionnaire as a method of analysis was introduced because of the difficulties of collecting face-to-face interviews in the universe of spin-offs and because of the necessity to have a standard set of questions for a comprehensive investigation. Furthermore, spin-off founders expressed preference for a written questionnaire instead of an interview because of lack of time and agenda organization. A written and standard questionnaire has the key advantage of giving standard answers available for an overall analysis and it helped obtain a high response rate, that gave us the possibility to overcome the limits of subjectivity in some answers. Main disadvantages of this tool of analysis are linked to the difficulty of highlighting specific particularities of each spin-off firm beyond the structure of the questionnaire and of obtaining information that respondents may be sensitive about providing in a mail questionnaire. Nonetheless, these gaps were partially filled through previous face-to-face interviews with selected case-studies. Some interviews were undertaken before drawing up the questionnaire as a crucial tool in order to understand the general context and check the main aspects of deep examination. The limits of a standard questionnaire were supplemented also by further information obtained through Internet searching. This approach enabled us to understand the most important features of this kind of firm and thus to draw up a questionnaire as much as possible linked to the particularities of spin-offs. Taking into consideration the results of the face-to-face interviews and the Internet searching, the final questionnaire was divided in several sections. In the following analysis we will focus on sections A "general characteristics of the spin-off firm", B "funding sources" and D "incubator/science park and spin-off firm relationship". We provide descriptive tables with data useful for understanding the overall characteristics of the sample and for highlighting the main significant answers emerged from the multiple choice questions. Nonetheless, in order to provide a more complete analysis, we are going to present first of all the results of a regression model built in order to show the influence of the number of science parks and incubators on the number of spin-offs established in Italian regions. A strongly significant coefficient relating to the science park-incubator independent variable illustrates a positive influence on the number of spin-offs. From this positive relationship in terms of number of hosting structures and number of firms we can assume the potential effectiveness of science parks and incubators. The questionnaire answers will analyse this effectiveness in practice by the point of view of the spin-off founders.

\section{The linear regression model}

After having identified the universe of spin-offs distributed in all the 20 Italian regions, we tried to find the number of science park and incubator structures in every region. Following the choice adopted by Link and Scott (2006) that used the constructed National Science Foundation database on university research parks, we started from the APSTI ${ }^{6}$ list of science park and incubator members at the Italian level. We filled the gaps in the number of these structures by looking at the questionnaire answers and through Internet 
searching. The final distribution of the universe is illustrated in Figure 1. [Insert Figure 1] We organized these variables and we built the regression model as follows.

\subsection{Dependent and independent variables}

We decided to use "spin-offs" as dependent variable in this analysis. The independent variables we employed were as follows: "science parks-incubators" measured as the number of science parks and incubators in the region. Finally, we controlled for "geographical location" by employing 3 dummy variables for North, Centre and South and Islands of Italy.

Descriptive statistics of the continuous variables are shown in table 1. The average number of research spin-off firms for the total sample was 20.95, while the average number of science parks-incubators was 2.9.

Table 1: Descriptive Statistics: total sample

\begin{tabular}{lccccc}
\hline Variable & Observations & Mean & Std. Dev. & Min & Max \\
\hline Spin-off & 20 & 20.95 & 19.12418 & 0 & 62 \\
Sc park-incubator & 20 & 2.9 & 2.807884 & 0 & 10 \\
\hline
\end{tabular}

\subsection{Method adopted and main results}

The regression model with spin-offs as dependent variable was estimated using ordinary least squares (OLS) regression analysis. We now discuss the regression results. Our aim was to verify whether there are any differences among the Italian regions in terms of spin-offs and science parks-incubators. Therefore, the final dataset included all the 20 Italian regions with and without spin-offs and science parks-incubators. We tested two different regression models. The two models were overall highly significant. Model 1 included only the continuous variables. Model 2 included both these variables and the dummy variables related to the geographical location of the regions. The two equations were strongly significant the results of which are presented in Model 1 and Model 2 tables.

In Model 1 we found a Prob $>F=0.0000$, a $R$-squared of 0.6208 and a strongly significant coefficient $(\mathrm{P}<0.01)$ relating to the science park-incubator variable. According to the results of Model 1, regions with more science parks and incubators have also a higher number of spin-offs of 5.37 in average.

Model 1

Linear regression $\quad$ Number of obs $=20$

$\mathrm{F}(1,18)=44.16$

Prob $>\mathrm{F} \quad=0.0000$

R-squared $=0.6208$

Root MSE $=12.099$

\begin{tabular}{|c|c|c|c|c|c|c|}
\hline Spin-off & Coef. & Robust Std. Err. & $\mathrm{t}$ & $\mathrm{P}>|\mathrm{t}|$ & \multicolumn{2}{|c|}{ [95\% Conf. Interval] } \\
\hline Sc park-incubator & 5.366489 & .8075685 & 6.65 & $0.000 * * *$ & 3.66985 & 7.063127 \\
\hline Constant & 5.387183 & 2.617836 & 2.06 & 0.054 & -.1126867 & 10.88705 \\
\hline
\end{tabular}

In Model 2 we found a Prob>F $=0.0000$ and the $R$-squared increased to 0.6418 . The strongly significant coefficient $(\mathrm{P}<0.01)$ relating to the science park-incubator variable remains the same. Furthermore, in this model we did not find a significant coefficient in relation to the dummy variables of the 
geographical location. According to the results of Model 2, regions with more science parks and incubators, as expected, have also a higher number of spin-offs of 5.12 in average.

Model 2

Linear regression $\quad$ Number of obs $=20$

$\mathrm{F}(3,16)=16.58$

Prob $>\mathrm{F}=0.0000$

R-squared $=0.6418$

Root MSE $=12.473$

\begin{tabular}{|c|c|c|c|c|c|c|}
\hline Spin-off & Coef. & Robust Std. Err. & $\mathrm{T}$ & $\mathrm{P}>|\mathrm{t}|$ & \multicolumn{2}{|c|}{ [95\% Conf. Interval] } \\
\hline Sc park-incubator & 5.117155 & .8043928 & 6.36 & $0.000 * * *$ & 3.411918 & 6.822391 \\
\hline North & 3.177824 & 6.326252 & 0.50 & 0.622 & -10.23323 & 16.58888 \\
\hline Centre & 7.574268 & 7.798694 & 0.97 & 0.346 & -8.958226 & 24.10676 \\
\hline South and Islands & (dropped) & & & & & \\
\hline Constant & 3.324268 & 3.192318 & 1.04 & 0.313 & -3.443144 & 10.09168 \\
\hline
\end{tabular}

\section{The 65 on-park and the 90 off-park research spin-offs}

We now focus on the 155 questionnaires. We divided the overall sample in the two groups of on-park (located in a science park or an incubator) and off-park (located outside a science park or an incubator) companies. We decided to investigate potential differences between on-park and off-park spin-offs because of the recurrence in many answers of the science park/incubator aid and of the completeness of the section devoted to these structures and spin-off firm relationship as well as of the result of the regression model. This high percentage enabled us to investigate the perceptions of tenant companies on the importance of these structures. Our analysis revealed that 65 research spin-offs out of 155 are tenant firms, while 90 are off-park companies. Surprisingly, findings showed few conclusive differences between the perceptions of on-park and off-park firms with the significant exceptions that on-park companies were on average more international oriented and more linked to the parent institute. The North and the Centre of the country are the most involved both in the on-park sample and in the off-park one. Aid by the incubator is, of course, perceived as a key solution for the management and business gap in the on-park sample. Similar choices are highlighted in the funding sources question. Finally, we found a significant confirmation that distance matters: the proximity of the science park-incubator to the university is considered as a key factor by most of the on-park sample.

Given the high number of questionnaires and the differences in the Italian context among the North, the Centre and the South of the country, first of all we looked at the location of the spin-off sample. From figure 2 we can observe how the geographical location of the 155 questionnaires received is over $50 \%$ for the North of Italy, nearly $20 \%$ for the South and just over $20 \%$ for the Centre. This distribution is almost the same for the location of the universe of 419 spin-offs at country level, as highlighted by figure 3. 
Figure 2: Distribution by Regions of the 155 questionnaires: graphical representation

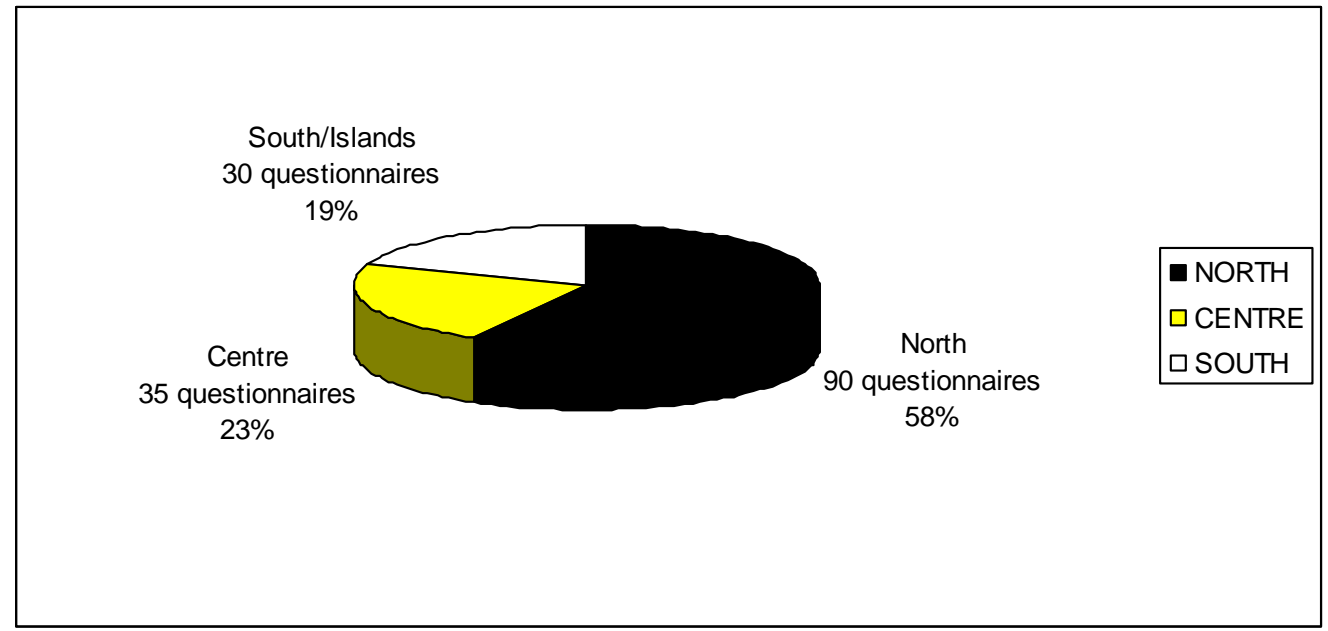

Figure 3: Italian distribution of the 419 spin-offs

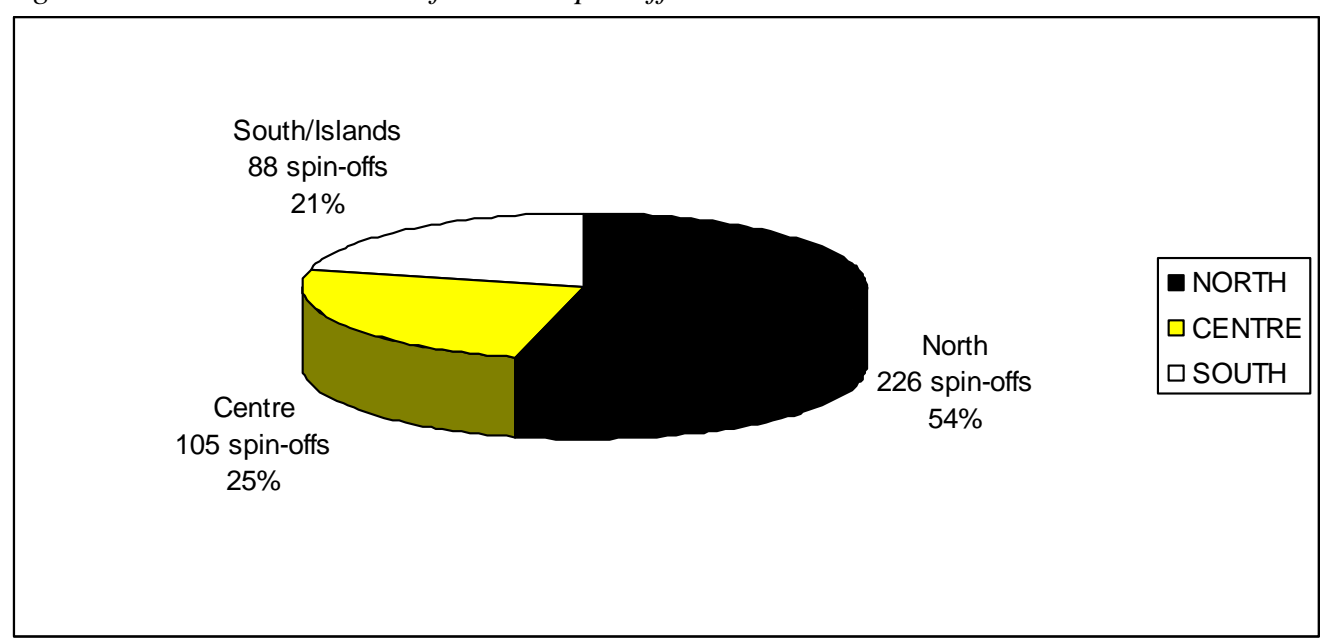

The country location (see Figure 4) of on-park and off-park research spin-offs revealed a similar distribution in the North of Italy with $52 \%$ of on-park companies and $48 \%$ of off-park ones, and a higher percentage of off-park firms in the Centre (71\%) than of on-park firms (29\%). Similarly, in the South and Islands it is observable a prevalence of off-park firms (73\%) than of on-park ones (27\%).

Figure 4: Number of on-park and off-park research spin-offs

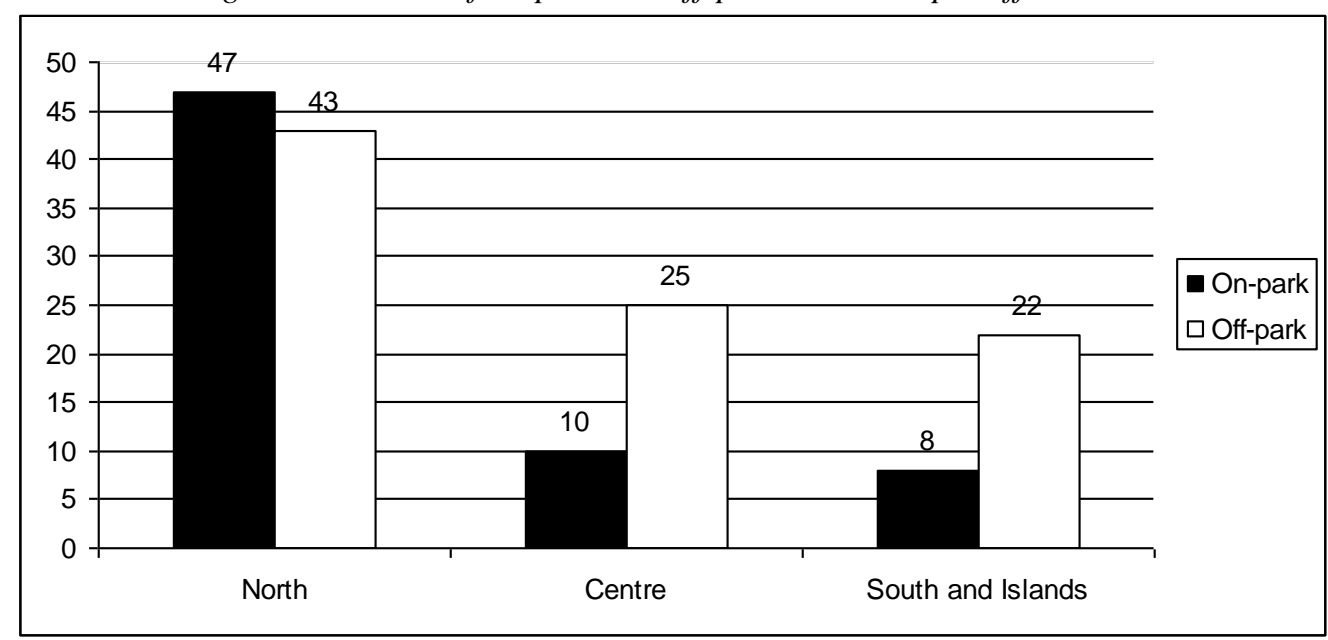


We now provide a description of the content of sections $\mathrm{A}, \mathrm{B}$ and $\mathrm{D}$ of the questionnaire. Tables reporting the frequencies of answer to single questions and the percentage will be defined and commented.

\subsection{Section A: similar micro firms but with a different market orientation and different entrepreneurial attitude}

Initial and present capital is low (between 10,000 and 20,000 euro) with few exceptions and no significant differences between on-park and off-park firms. The number of employees is between 2 and 4 : this low number confirms the finding of the empirical investigation undertaken by Chiesa and Piccaluga (2000) at the end of the 1990s on a sample of 48 Italian spin-offs.

A comparison between the legal form of tenant spin-offs and off-park spin-offs revealed a prevalence in both cases of limited companies (Table 2). The five joint-stock companies are all off-park spin-offs. The five limited partnerships of all the sample are, instead, on-park firms.

Table 2: Legal form of the research spin-off firm

\begin{tabular}{lcccc}
\hline Possible answers & On-park Spin-offs & $\%$ & Off-park Spin-offs & $\%$ \\
\hline Limited companies & 60 & $92 \%$ & 84 & $93 \%$ \\
Joint-stock companies & 0 & $0 \%$ & 5 & $6 \%$ \\
Limited partnerships & 5 & $8 \%$ & 0 & $0 \%$ \\
No answer & 0 & $0 \%$ & 1 & $1 \%$ \\
Total & 65 & $100 \%$ & 90 & $100 \%$ \\
\hline
\end{tabular}

The comparison in terms of product and service companies showed again a similar distribution between on-park and off-park firms (Table 3). The conceptual distinction between service and product orientated spin-offs has been confirmed in various empirical studies (Wright et al., 2007; Mustar et al., 2006).

\begin{tabular}{lcccc} 
Table 3: The spin-off firm is \\
\cline { 2 - 5 } & $\begin{array}{c}\text { On park } \\
\text { Spin-off }\end{array}$ & $\mathbf{\%}$ & $\begin{array}{c}\text { Off-park } \\
\text { Spin-off }\end{array}$ & $\%$ \\
\hline Product company & 22 & $33.8 \%$ & 29 & $32.20 \%$ \\
Service company & 43 & $66.2 \%$ & 61 & $67.08 \%$ \\
Total & 65 & $100.00 \%$ & 90 & $100.00 \%$ \\
\hline
\end{tabular}

The industry sectors comparison revealed that most of on-park firms are in the biopharmaceutical (40\%) and the ICT sectors (31\%), while off-park companies are most of all in the ICT (36\%) and in the engineering sectors (29\%), (see Figure 5). While the Internet revolution (Benghozi et al., 2009; Borrás, 2003) had certainly a deep influence in the high number of companies in the ICT industry, according to Shane (2004) possible explanations for biopharmaceutical being fertile grounds for the creation of spin-offs are linked to the long product development horizons, to the expertise of universities in the creation of biomedical inventions and to the possibility to use resources and laboratories. And our result in terms of industry sectors is coherent with other empirical surveys at the European level, like the one on German spinoffs (Gupte, 2007), the one on Swedish on-park and off-park firms (Lindelof, Lofsten, 2004) and the one on French spin-offs (Mustar, 1997). 
Figure 5: Industry sectors of the 65 on-park and the 90 off-park research spin-offs

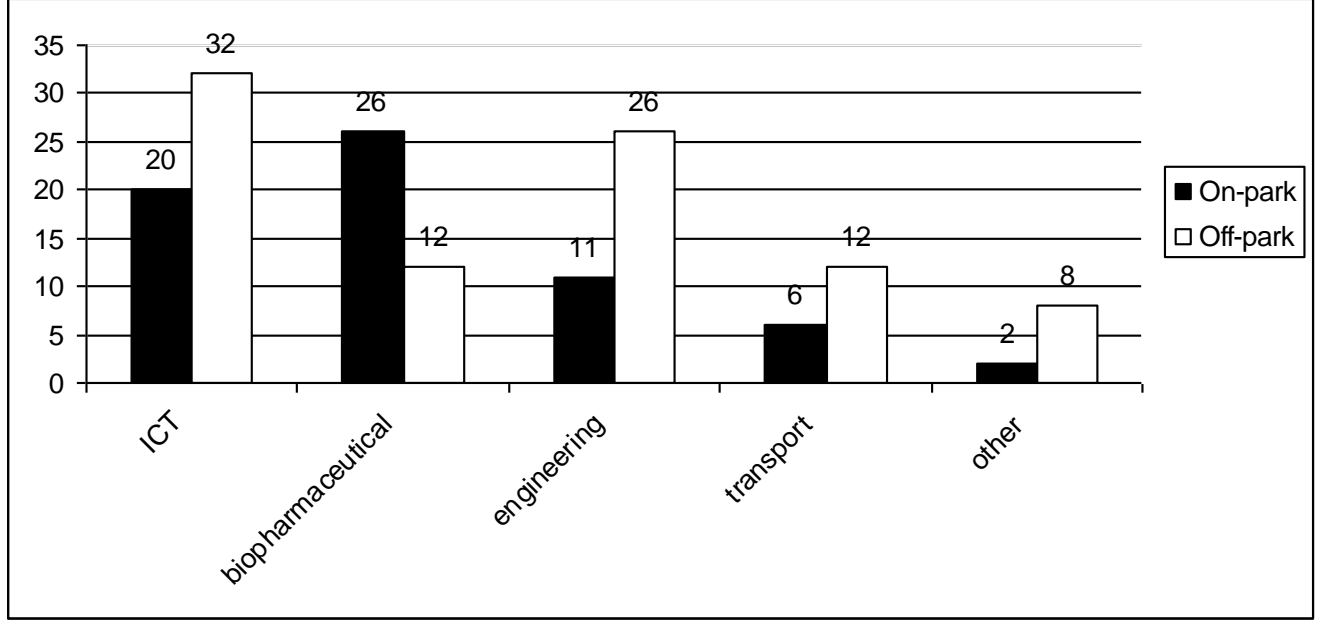

An interesting result was given by the comparison about the market on which these companies deal. Figure 6 highlights that $55 \%$ of on-park spin-offs deals on the international market while only $34 \%$ works on the national market. The results for the sample of off-park spin-offs is exactly the opposite (Figure 7). Therefore, we can argue that notwithstanding their small size, Italian research spin-offs have a high international attitude and they are strongly not limited to the local-regional level. This result is coherent with the literature (McDougall, Oviatt, 1996; Autio, Yli-Renko, 1998; Chiesa, Piccaluga, 2000; Harrison, Leitch, 2007).

Figure 6: The 65 on-park research spin-offs deal on the market:

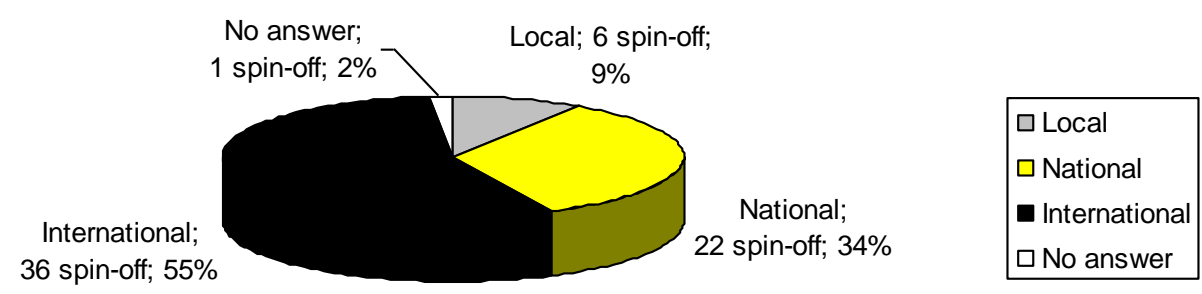


Figure 7: The 90 off-park research spin-offs deal on the market:

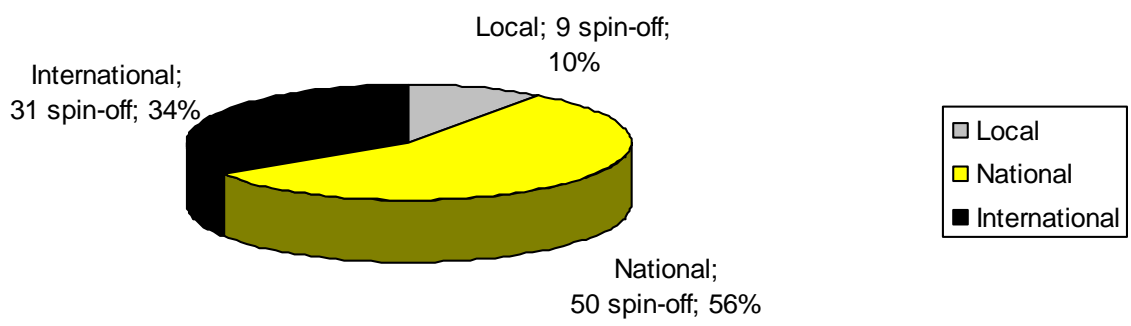

The motivations for the creation of the firm revealed in both the samples the prevalence of the willingness to use research results and to commercialize ideas (Tables 4 and 5). Nonetheless, if these choices are very evident in the sample of off-park spin-offs, in on-park firms, instead, it is also observable a high percentage of "desire of independence" and "lack of job in the university". The independence attitude (O'Shea et al., 2005; Shane, 2004) is more prevalent in the on-park sample than in the off-park one: the condition of tenant company is, therefore, not considered as a restriction of autonomy. Similarly, the high percentage of "lack of job in the university" choices is probably linked to the fact that spin-off founders do not want to lose the links with the parent institute.

Table 4: Reasons for the creation of on-park firm

\begin{tabular}{lcccc}
\hline Possible answers & \multicolumn{2}{c}{ First choice } & \multicolumn{2}{c}{ Second choice } \\
\hline & $\begin{array}{c}\text { On-park } \\
\text { Spin-off }\end{array}$ & $\%$ & $\begin{array}{c}\text { On-park } \\
\text { Spin-off }\end{array}$ & $\%$ \\
1-Lack of job in the University & 7 & $11 \%$ & 11 & $17 \%$ \\
2-Desire of independence & 11 & $17 \%$ & 13 & $20 \%$ \\
3-Desire to work in "a business way" & 5 & $8 \%$ & 10 & $15 \%$ \\
4-Use research results & 24 & $37 \%$ & 13 & $20 \%$ \\
5-Go from the idea to the market & 13 & $20 \%$ & 10 & $15 \%$ \\
6-Personal prestige & 0 & $0 \%$ & 4 & $6 \%$ \\
7-Other (a mix of 1, 2, 4,5) & 5 & $8 \%$ & 3 & $5 \%$ \\
No answers & 0 & $0 \%$ & 1 & $2 \%$ \\
Total & 65 & $100 \%$ & 65 & $100 \%$ \\
\hline
\end{tabular}

Table 5: Reasons for the creation of off-park firm

\begin{tabular}{lcccc}
\hline Possible answers & \multicolumn{2}{c}{ First choice } & \multicolumn{2}{c}{ Second choice } \\
\hline & $\begin{array}{c}\text { Off -park } \\
\text { Spin-off }\end{array}$ & $\%$ & $\begin{array}{c}\text { Off-park } \\
\text { Spin-off }\end{array}$ & $\%$ \\
1-Lack of job in the University & 13 & $14 \%$ & 11 & $12 \%$ \\
2-Desire of independence & 12 & $13 \%$ & 12 & $13 \%$ \\
3-Desire to work in "a business way" & 6 & $7 \%$ & 13 & $14 \%$ \\
4-Use research results & 31 & $34 \%$ & 22 & $24 \%$ \\
5-Go from the idea to the market & 22 & $24 \%$ & 21 & $23 \%$ \\
6-Personal prestige & 0 & $0 \%$ & 0 & $0 \%$ \\
7-Other (a mix of 1, 2, 4,5) & 5 & $6 \%$ & 5 & $6 \%$ \\
No answers & 1 & $1 \%$ & 6 & $7 \%$ \\
Total & 90 & $100 \%$ & 90 & $100 \%$ \\
\hline
\end{tabular}


Managerial and business gap is a characteristic well highlighted in the literature on this kind of firm (Shane, Stuart, 2002; Lockett et al., 2003; Heirman, Clarysse, 2004; Wright et al., 2004; Shane, 2004; Salvador, 2010). The solution to lack of managerial competence revealed a high prevalence of the aid provided by the incubator for on-park spin-offs, as expected, followed by a self-training solution. The sample of off-park firms, instead, showed a strong prevalence of self-training and absence of any difficulties (Table 6). Therefore, we can assume that the knowledge gap seems more prevalent in on-park spin-offs, because only $6 \%$ of the on-park sample chose "no lacks".

Table 6: Solutions for lack of managerial competence

\begin{tabular}{lcccc}
\hline Possible answers & \multicolumn{2}{c}{ First choice } & \multicolumn{2}{c}{ First choice } \\
\hline & $\begin{array}{c}\text { On-park } \\
\text { Spin-off }\end{array}$ & $\%$ & $\begin{array}{c}\text { Off-park } \\
\text { Spin-off }\end{array}$ & $\%$ \\
1-External manager & 5 & $8 \%$ & 16 & $18 \%$ \\
2-Aid by the incubator & 29 & $45 \%$ & 0 & $0 \%$ \\
3-Self-training & 23 & $35 \%$ & 31 & $34 \%$ \\
4-Aid by the industrial partner & 4 & $6 \%$ & 9 & $10 \%$ \\
5-No lacks & 4 & $6 \%$ & 29 & $32 \%$ \\
No answer & 0 & $0 \%$ & 5 & $6 \%$ \\
Total & 65 & $100 \%$ & 90 & $100 \%$ \\
\hline
\end{tabular}

\subsection{Section B: the science park-incubator aid is not perceived as very significant}

The comparison on the sources of finance revealed a similar choice: personal and family capital (Roberts, 1991) and public grants (Wright et al., 2006) are the sources most utilized in both the groups (Table 7).

Table 7: Financial resources

\begin{tabular}{lcc}
\hline Possible choices (multiple answers) & On-park Spin-off & Off-park spin-off \\
\hline Personal and family capital & 52 & 79 \\
Bank loans & 6 & 8 \\
Regional, National, European grants; Start-Cup; National & 38 & 36 \\
Innovation Prize & 3 & 5 \\
Venture Capital/Business Angels & 7 & 5 \\
Other forms of support & & \\
\hline
\end{tabular}

Similarly, the question about the relationship with banks revealed nearly the same distribution in the answers provided by on-park and off-park samples (Table 8). The absence of difficulties is the prevalent choice, followed by lack of competence by firms or by banks. The lack of expertise of banks has been yet highlighted in the literature (Colombo, Delmastro, 2002).

Surprisingly, in this field aid provided by the science park-incubator is not perceived as very significant in on-park sample.

Table 8: Relationship with banks

\begin{tabular}{lcccr}
\hline Possible answers & $\begin{array}{c}\text { On-park } \\
\text { Spin-off }\end{array}$ & $\%$ & $\begin{array}{c}\text { Off-park } \\
\text { Spin-off }\end{array}$ & $\%$ \\
\hline 1-Difficult for lack of competence by spin- & 10 & $15 \%$ & 13 & $14 \%$ \\
off firm & 9 & $14 \%$ & 15 & $17 \%$ \\
2-Difficult for lack of competence by banks & 6 & $9 \%$ & 0 & $0 \%$ \\
3-Pivotal aid of the incubator & 2 & $3 \%$ & 5 & $6 \%$ \\
4-Pivotal aid of the University & & & & \\
\hline
\end{tabular}




\begin{tabular}{lcccr}
\hline 5-No difficulties & 34 & $52 \%$ & 49 & $54 \%$ \\
No answer & 3 & $5 \%$ & 8 & $9 \%$ \\
No relationship & 1 & $2 \%$ & 0 & $0 \%$ \\
Total & 65 & $100 \%$ & 90 & $100 \%$ \\
\hline
\end{tabular}

\subsection{Section D: the proximity to the parent institute is a key factor for on-park spin-offs}

This section analyses the relationship between on-park spin-off and the incubator or the science park. The questionnaire results highlighted a prevalence of science park/incubator tenant companies in the North of Italy compared to the Centre and the South of the country. Table 9 provides a summary of the hosting period. Only 15 spin-off firms have finished their period of incubation at the time of investigation, the others are still in an incubator-science park. An increase in the number of tenant companies is observable since 2005. This is a consequence of the high number of research spin-offs created since 2004 and of the great attention devoted to this phenomenon by Italian universities in recent years (Salvador, 2009).

Table 9: Period of incubation

\begin{tabular}{lcc}
\hline Time period & Spin-off & \% \\
\hline From 1997- & 1 & 0.65 \\
$1999-2002$ & 2 & 1.29 \\
From 2000- & 1 & 0.65 \\
$2000-2002$ & 2 & 1.29 \\
$2000-2007$ & 1 & 0.65 \\
$2001-2004$ & 1 & 0.65 \\
From 2003- & 2 & 1.29 \\
$2003-2005$ & 1 & 0.65 \\
$2003-2006$ & 1 & 0.65 \\
$2003-2007$ & 1 & 0.65 \\
From 2004- & 2 & 1.29 \\
$2004-2008$ & 1 & 0.65 \\
From 2005- & 6 & 3.87 \\
$2005-2006$ & 1 & 0.65 \\
$2005-2007$ & 1 & 0.65 \\
From 2006- & 11 & 7.10 \\
2006-2007 & 2 & 1.29 \\
2006-2008 & 1 & 0.65 \\
From 2007- & 16 & 10.32 \\
From 2008- & 7 & 4.52 \\
No answer and not hosted & 94 & 60.65 \\
Total & 155 & 100.00 \\
\hline
\end{tabular}

According to the literature (Squicciarini, 2008; Ferguson, Olofsson, 2004) the most important advantages coming from the hospitality are the possibility to use the services provided by the structure, the rent less expensive than on the market, the greater visibility (see Table 10).

Table 10: Advantages coming from the hospitality in an incubator or science park

\begin{tabular}{lcccc}
\hline Possible anwers & \multicolumn{2}{c}{ First advantage } & \multicolumn{2}{c}{ Second advantage } \\
\hline & Spin-off & $\%$ & Spin-off & $\%$ \\
1-More visibility & 10 & 6.45 & 10 & 6.45 \\
2-Prestige & 0 & 0.00 & 4 & 2.58 \\
3-Use the services provided & 34 & 21.94 & 17 & 10.97 \\
4-Rent less expensive & 13 & 8.39 & 11 & 7.10 \\
5-Guarantee of reliability & 1 & 0.65 & 8 & 5.16 \\
\hline
\end{tabular}




\begin{tabular}{lcccc}
\hline 6-More easiness in finding clients & 3 & 1.94 & 7 & 4.52 \\
7-Other & 3 & 1.94 & 1 & 0.65 \\
No answer & 1 & 0.65 & 7 & 4.52 \\
Not hosted & 90 & 58.06 & 90 & 58.06 \\
Total & 155 & 100.00 & 155 & 100.00 \\
\hline
\end{tabular}

In the literature, critical issues concern what incubators and science parks offer besides physical space (Mustar et al., 2006). We tried to investigate which kinds of facilities are most utilized by tenant companies and which ones are lacking. The questionnaire results show that "meetings organised by the incubatorscience park with business personalities" and "open spaces for meetings" are the most appreciated, followed by "networking with other firms", "tutorship" and "consulency" services (Table 11). The importance of an efficent network has been underlined by the empirical investigation by Pérez Pérez and Sànchez (2003). Furthermore, Autio and Yli-Renko (1998) underlined that the diffusion of ICT lowered the threshold for outsourcing of activities, thus encouraging flexible specialisation and networking between firms.

Table 11: Science park-incubator services utilized

\begin{tabular}{|c|c|c|c|c|}
\hline Possible answers & Yes & No & No answer and not hosted & Total \\
\hline Tutorship & 30 & 34 & 91 & 155 \\
\hline Consulency & 29 & 35 & 91 & 155 \\
\hline Network of private investors & 7 & 57 & 91 & 155 \\
\hline Networking with other firms & 31 & 33 & 91 & 155 \\
\hline $\begin{array}{l}\text { Networking with university } \\
\text { departments }\end{array}$ & 22 & 42 & 91 & 155 \\
\hline Meeting organized by incubator & 41 & 23 & 91 & 155 \\
\hline $\begin{array}{l}\text { Conference room and common } \\
\text { spaces }\end{array}$ & 49 & 15 & 91 & 155 \\
\hline
\end{tabular}

The overall assessment on the hospitality provided by the structure is positive (Table 12) and more than half of the on-park sample consider of key importance a geographical proximity of the incubatorscience park to the university (Table 13). This result is an important confirmation of the finding by Link and Scott $(2003,2005,2006,2007)$ that distance matters and that spin-offs tend to locate near their parent organization (Harrison, Leitch, 2007). They found that those US universities with research parks closer to their campus have a greater percentage of research spin-off firms. Similarly, Zhang (2009) found that more than two-thirds of a sample of US venture-backed research spin-offs are located in the same state as the parent institute and Steffensen et al. (1999) asserted that spin-offs from the university of New Mexico generally were located near the university. The empirical analysis undertaken by Lindelof and Lofsten (2004) on Swedish on-park and off-park tenants, illustrated that proximity between these firms and universities fosters the establishment of networks and therefore it promotes the exchange of ideas. The higher degree of networking activity is dependent on the geographical proximity. Furthermore, Shane (2004) highlighted that spin-offs tend to locate close to the universities that spawn them and he underlined how a flexible approach of the university to its relationship with the spin-offs enhances their performance because such an approach allows the relationship to adapt to changing environmental circumstances. Bellavista and Sanz (2009: 502) consider "efficient links to one or more universities" as the second main building block of 
science and technology parks. Wessner (2009) argued that, as explained by Saxenian, greater geographic proximity encourages repeated interaction that helps build the mutual trust needed to sustain cooperation. The importance of trust encouraged by repeated face-to-face interactions has led Saxenian (1994: 161, cited in Wessner, 2009: 23) to observe that "paradoxically regions offer an important source of competitive advantage even as production and markets become increasingly global". This assertion is linked to the importance of network relationship-building that, according to Bellavista and Sanz (2009) is an essential element of every science park and according to Hackett and Dilts (2004) enhance the likelihood of incubation success.

Table 12: Judgement of the hospitality in an incubator or science park

\begin{tabular}{lc}
\hline Possible answers & Spin-off \\
\hline 1-excellent & 20 \\
2-good & 21 \\
3-sufficient & 15 \\
4-poor & 4 \\
5-insufficient & 3 \\
No answers & 2 \\
Not hosted & 90 \\
Total & 155 \\
\hline
\end{tabular}

Table 13: Geographical proximity to the university

\begin{tabular}{lc}
\hline Possible answers & Spin-off \\
\hline 1-it's a pivotal factor & 37 \\
2-it's a factor of little importance & 16 \\
3-it's of no importance & 10 \\
No answers & 2 \\
Not hosted & 90 \\
Total & 155 \\
\hline
\end{tabular}

\section{Some concluding remarks}

The research spin-off scenario in Italy is complex, confused and difficult to qualify. If it is true that the spin-off phenomenon is a new reality for a country like Italy and it has acquired more and more importance in recent years, it is also true that it is a not well definite subject. Notwithstanding the great attention towards this phenomenon, lack of clarity and information characterize the Italian research spin-off context. The main instrument that has recently been introduced is a specific spin-off set of rules by many Italian universities, following the Legislative Decree n. 297/1999 (Salvador, 2009).

In this paper we provided original evidence on Italian research spin-offs. The empirical analysis followed a two stage process. First of all we provided a linear regression model with spin-offs as dependent variable. Second, we made use of primary data sources that captured data directly from the spin-off firms: descriptive statistics were computed for a set of 65 on-park and 90 off-park respondents.

Our empirical investigation revealed that the actual number of Italian research spin-offs is over 400 companies. Nonetheless, according to Harrison and Leitch (2007), the number of spin-offs alone is not a sufficient indicator of success because this ignores their initial scale as well as their potential to grow and survive. In fact, notwithstanding the increasing number of this kind of firm in recent years, our empirical 
investigation revealed that Italian research spin-offs are very small, "micro firms" rather than SMEs according to the current classification of the European Union. Our result is coherent with the literature on this issue (Harrison, Leitch, 2007; Autio, Lumme, 1998; Autio, 1997; Stankiewicz, 1994). Autio and YliRenko (1998: 974) underlined the fact that the great majority of new technology-based firms will never be other than micro firms, because growth is not a key goal. "Successful NTBFs in the Information Society could prefer to remain small and be less concerned with growth".

The comparison between on-park and off-park spin-offs revealed an absence of significant differences, with few exceptions. Nonetheless, similar choices by on-park and off-park respondents call for a further research on the efficacy and effectiveness of the aid provided by science parks and incubators. It is interesting to remember that Bearse (1998) asked whether Harvard students (the incubatees) succeeded because of what Harvard (the incubator) did to them or because of the selection criteria undertaken by Harvard that selected only students of success regardless of what Harvard did to them. Furthermore, according to Link and Scott (2007), the growth in science parks has stimulated an academic debate concerning whether such property-based initiatives directly enhance the performance of universities and economic regions over time. Finally, Link and Scott (2007: 669) reviewed several academic papers that find very few or no significant differences between on-park and off park firms and they concluded that "localized spillovers from parks are not as great as they could be". The results of our investigation confirmed that distance matters (Link, Scott, 2003, 2005, 2006, 2007) and the regression model confirmed the hypothesis that research spin-off firms are growing in number where there is an higher number of science parks and incubators. This process is developing like the path dependency suggested by David (1985). This argument is in line with the results of the analysis undertaken by Nosella and Grimaldi (2009: 692 and 694): "localisation of university is statistically significant, thus affecting the generation of academic spin-offs" and "universities located in the north and more industrialised part of Italy are more likely to generate spin-offs, confirming the importance of a fertile local context to enhance the creation of new companies".

In conclusion, the results of our investigation on the Italian research spin-off phenomenon seem to confirm the literature finding that most attention has been focused on spin-off creation and not on increasing the probability that these firms are sustainable in the long run (Siegel et al., 2007). According to Kakko and Inkinen (2009: 542), "There is an urgent need to implement new approaches to the world of S\&T parks. (...) The key challenge is how to successfully incorporate new theories and models into practice". De Miranda et al. (2009) argued that science parks and incubators are linked with the helixes of their proposed triple helix model for the creative industry and they stressed the potential of creativity. In our opinion, an effective evaluation of the aid provided by science parks and incubators at the national level could be of pivotal importance for a spin-off working "well". The analysis highlighted a positive but not very significant assessment of the science park-incubator collaboration and aid provided. A further step following the new university policy of spin-off regulations issuing could be to provide more attention towards the link between science parks-incubators and spin-offs: this focus could foster the role of "brand names" (Salvador, 2010) of science parks and incubators as well as improve the effectiveness of these actors as a solution to "the 
knowledge gap" (Lockett et al., 2003; Wright et al., 2004; Shane, 2004; Roberts, 1991) and "the liability of newness" (Ferguson, Olofsson, 2004; Schwartz, 2009; Sofouli, Vonortas, 2007).

It is important to foster the potentialities of the finding that the number of science parks and incubators has a positive influence on the one of spin-offs. Italy has provided great attention to these hosting structures in recent years but this is not enough. The questionnaire analysis did not highlight significant better results for on-park spin-offs compared to off-park ones. Science parks and incubators seem not to be as effective as they could be for research spin-offs. Nevertheless, the positive judgement of the hospitality and the key importance of the geographical proximity of the hosting structures to the university as well as the international attitude of on-park spin-offs are pivotal proofs of the goodness of the policy in progress. In our opinion, this calls for a need for improvement rather than an overall change of policy. Policymakers and stakeholders should pay more attention to spin-off perceptions rather than follow general policy prescriptions in order to make these structures not only "accompanying" but also "decisive" factors for research spin-off firms.

This study is not without its limitations and potential biases. First of all, we had a population of research spin-offs that did not cover the universe. Nonetheless, the sample was well distributed in the North, the Centre and the South of the country. Therefore, we reasonably considered this sample as representative. Furthermore, we were able to obtain a large number of questionnaire respondents: the response rate was $39.5 \%$. Thus, we were able to provide an extensive survey on the main perceptions of Italian research spinoff founders. The results reported here could be tested in even larger samples in the future in order to prove our findings. Second, our study is limited to the Italian context and do not attempt at providing a cross analysis with other European countries. Future research with comparisons between Italy and other countries could be advisable in order to test our results. Finally, our analysis relied on data covered on a given time period. It would be useful to undertake another questionnaire investigation in the same sample of companies after a few years, as Mustar (1997) did in France, in order to compare old and new answers and to analyse the rate of survival and death of these firms.

Despite these limitations and potential biases, our empirical investigation was useful in order to better understand the Italian research spin-off phenomenon and to stimulate further research along this line. In our opinion, these limitations can only be overcome in future research by collecting more and reliable data that actually are not available. In particular, in the next future it would be useful to measure performance by collecting financial data through balance sheets and to compare university spin-offs with spin-offs established from public research organizations such as the National Research Council. Science parks, incubators, TTOs and ILOs are important resources and they may be key solutions to many difficulties and problems faced by research spin-offs. The actual challenge for Italian universities and policymakers is to optimize the role and the effective function of these structures so that they may be really useful for the research spin-off phenomenon and this last one would not be limited to a role of self-celebration of Italian universities. 
${ }^{1}$ In the following analysis we will use frequently the expression "new technology-based firms (NTBF)" as inclusive also of spin-off firms, because many empirical papers include in the category of NTBFs spin-offs and start-ups. According to Hogan and Hutson (2007: 91), "NTBFs are defined as independent ventures less than 25 years old that supply a product or service based on the exploitation of an invention or technological innovation".

2 An extensive review of the literature on incubators and a list of definitions culled from the literature is provided by Hackett, Dilts (2004).

${ }^{3}$ See Rowe (2002), ANGLE Technology (2003), Parry, Russell (2000), Siegel et al. (2003) for the UK; Mian (1996) and Rothaermel, Thursby (2005) for the US; Colombo, Delmastro (2002) for Italy; Schwartz (2009) for Germany; Sofouli, Vonortas (2007) for Greece.

${ }^{4}$ See, for example, Westhead, Storey, 1995; McDougall, Oviatt, 1996; Autio, 1997; Mustar, 1997; Autio, Lumme, 1998; Steffensen et al., 1999; Klofsten, Jones-Evans, 2000; Chiesa, Piccaluga, 2000; Franklin et al., 2001; Shane, Stuart, 2002; Colombo, Delmastro, 2002; Pérez Pérez, Sànchez, 2003; Heirman, Clarysse, 2004; Lindelof, Lofsten, 2004; Wright et al., 2004; Fontes, 2005; Link, Scott, 2005; Clarysse et al., 2007; Gupte, 2007; Zahra et al., 2007; Squicciarini, 2008; Schwartz, 2009; Fini et al., 2009.

${ }^{5}$ This list is updated at 2008 (year of the empirical investigation through questionnaires).

${ }^{6}$ APSTI - Association of Italian Scientific and Technological Parks is the national network to which the majority of Italian parks have joined to, to support economic development through innovation.

\section{References}

Amin A., Thrift N. (2001), "Living in the global", in Amin A. and Thrift N., eds. Globalization, institutions and regional development in Europe, Oxford, Oxford university Press.

ANGLE Technology (2003) "Evaluation of the past \& future economic contribution of the UK Science Park Movement", London: UKSPA.

Autio E., Lumme A. (1998), "Does the innovator role affect the perceived potential for growth? Analysis of four types of new, technology-based firms", Technology Analysis \& Strategic Management, vol. 10, n. 1, pp. 41-54.

Autio E., Yli-Renko H. (1998), "New, technology-based firms in small open economies - An analysis based on the Finnish experience", Research Policy, vol. 26, n. 9, pp. 973-987.

Autio, E. (1997), "New, technology-based firms in innovation networks symplectic and generative impacts", Research Policy, vol. 26, n. 3, pp. 263-281.

Bearse P. (1998), “A question of evaluation: NBIA's impact assessment of business incubators", Economic Development Quarterly, vol. 12, n. 4, pp. 322-333.

Bellavista J., Sanz L. (2009), "Science and technology parks : habitats of innovation : introduction to special section", Science and Public Policy, vol. 36, n. 7, pp. 499-510.

Benghozi, P.-J., Bureau, S., Massit-Folléa, F. (2009), “L'internet des objets : quels enjeux pour l'Europe ?”, Editions de la Maison des Sciences de l'Homme, Paris.

Borrás S. (2003), "The innovation policy of the European Union. From government to governance", Northampton MA, USA, Edward Elgar.

Cesaroni, F. et Gambardella, A. (1999), "Dai "contenitori" ai "contenuti": i parchi scientifici e tecnologici in Italia", in Antonelli, C., ed. (1999), "Conoscenza tecnologica: nuovi paradigmi dell'innovazione e specificità italiana", Torino, Fondazione Giovanni Agnelli.

Chiesa, V. et Piccaluga, A. (2000), "Exploitation and diffusion of public research: the case of academic spin-off companies in Italy", $R \& D$ Management, vol. 30, n. 4, pp. 329-340.

Clarysse B., Lockett A., Quince T., Van de Velde E. (2002), "Spinning off new ventures: a typology of facilitating services", Institute for the Promotion of Innovation by Science and Technology in Flanders, IWT-Observatory, Innovation, Science, Technology, n. 41.

Clarysse B., Wright M., Lockett A., Mustar P., Knockaert M. (2007), "Academic spin-offs, formal technology transfer and capital raising", Industrial and Corporate Change, vol. 16, n. 4, pp. 609-640.

Colombo, M. G. et Delmastro, M. (2002), "How effective are technology incubators? Evidence from Italy", Research Policy, vol. 31, n. 7, pp. 1103-1122.

David P. A. (1985), "Clio and the Economics of QWERTY", The American Economic Review, vol. 75, n. 2, pp. 332337. 
Degroof J.-J., Roberts E. (2003), "Spinning-off new ventures from academic institutions in areas with weak entrepreneurial infrastructure: insights on the impact of spin-off processes on the growth-orientation of ventures”, MIT Sloan School of Management, Working Paper 4311-03.

Degroof J.-J., Roberts E. (2004), “Overcoming weak entrepreneurial infrastructures for academic spin-off ventures”, MIT, Industrial Performance Center, Working Paper Series, MIT-IPC-04-005.

De Miranda P. C., Aranha J. A. S., Zardo J. (2009), “Creativity : people, environment and culture, the key elements in its understanding and interpretation”, Science and Public Policy, vol. 36, n. 7, pp. 523-535.

Ferguson R., Olofsson C. (2004), "Science parks and the development of NTBFs. Location, survival and growth", Journal of Technology Transfer, vol. 29, n. 1, p. 5-17.

Fini R., Grimaldi R., Sobrero M. (2009), "Factors fostering academics to start up new ventures: an assessment of Italian founders'incentives", Journal of Technology Transfer, vol. 34, n. 4, pp. 380-402.

Finlombarda (2006), "Finanza e innovazione. Quinto quaderno sugli strumenti di finanza innovativa a supporto degli spin-off accademici”, Milano.

Fontes M. (2005), "The process of transformation of scientific and technological knowledge into economic value conducted by biotechnology spin-offs", Technovation, vol. 25, n. 4, pp. 339-347.

Franklin S. J., Wright M., Lockett A. (2001), “Academic and surrogate entrepreneurs in university spin-out companies”, Journal of Technology Transfer, vol. 26, n. 1-2, pp. 127-141.

Gilsing V. A., van Burg E., Romme A. G. L. (2010), "Policy principles for the creation and success of corporate and academic spin-offs", Technovation, vol. 30, n. 1, pp. 12-23.

Gupte, M. (2007), "Success of University Spin-offs. Network Activities and Moderating Effects of Internal Communication and Adhocracy”, Kiel, Deutscher Universitats-Verlag.

Hackett S. M., Dilts D. M. (2004), “A systematic review of business incubation research”, Journal of Technology Transfer, vol. 29, n. 1, pp. 55-82.

Harrison R. T., Leitch C. M. (2007), "Dynamics of university spin-out companies: entrepreneurial ventures or technology lifestyle businesses?", in Clarysse B., Roure J., Schamp T. (2007b), eds., "Entrepreneurship and the Financial Community. Starting up and growing new businesses", Cheltenham UK, Edward Elgar.

Heirman A., Clarysse B. (2004), "How and why do research-based start-ups differ at founding? A resource-based configurational perspective", Journal of Technology Transfer, vol. 29, n. 3-4, pp. 247-268.

Hindle K., Yencken J. (2004), "Public research commercialisation, entrepreneurship and new technology based firms: an integrated model", Technovation, vol. 24, n. 10, pp. 793-803.

Hogan T., Hutson E. (2007), "What factors determine the use of venture capital? Evidence from the Irish software sector", in Clarysse B., Roure J., Schamp T. (2007b), eds., "Entrepreneurship and the Financial Community. Starting up and growing new businesses", Cheltenham UK, Edward Elgar.

Kakko I., Inkinen S. (2009), "Homo creativus : creativity and serendipity management in third generation science and technology parks", Science and Public Policy, vol. 36, n. 7, pp. 537-548.

Klofsten M., Jones-Evans D. (2000), “Comparing academic entrepreneurship in Europe. The case of Sweden and Ireland”, Small Business Economics, vol. 14, n. 4, pp. 299-309.

Lindelof P., Lofsten H. (2004), "Proximity as a resource base for competitive advantage: university-industry links for technology transfer", Journal of Technology Transfer, vol. 29, n. 3-4, pp. 311-326.

Link A. N., Scott J. T. (2005), “Opening the ivory tower's door: an analysis of the determinants of the formation of U. S. university spin-off companies”, Research Policy, vol. 34, n. 7, pp. 1106-1112.

Link A. N., Scott J. T. (2003), "U.S. science parks: the diffusion of an innovation and its effects on the academic missions of universities", International Journal of Industrial Organization, vol. 21, n. 9, pp. 1323-1356.

Link A. N., Scott J. T. (2006), “U.S. University Research Parks”, Journal of Productivity Analysis, vol. 25, n. 1-2, pp. 43-55.

Link A. N., Scott J. T. (2007), “The economics of university research parks", Oxford Review of Economic Policy, vol. 23, n. 4, pp. 661-674.

Lockett A., Wright M. (2005), "Resources, capabilities, risk capital and the creation of university spin-out companies", Research Policy, vol. 34, n. 7, pp. 1043-1057. 
Lockett, A., Wright, M. et Franklin, S. (2003), “Technology Transfer and Universities'Spin-Out Strategies”, Small Business Economics, vol. 20, n. 2, pp. 185-200.

McDougall P., Oviatt B. (1996), "New venture internationalization, strategic change and performance: a follow-up study", Journal of Business Venturing, vol. 11, n. 1, pp. 23-40.

Mian, S. A. (1996), "Assessing value-added contributions of university technology business incubators to tenant firms", Research Policy, vol. 25, n. 3, pp. 325-335.

Mustar P. (1997), "Spin-off enterprises. How French academics create hi-tech companies: the conditions for success or failure", Science and Public Policy, vol. 24, n. 1, pp. 37-43.

Mustar P., Renault M., Colombo M., Piva E., Fontes M., Lockett A., Wright M., Clarysse B., Moray N. (2006), "Conceptualising the heterogeneity of research-based spin-offs: a multi-dimensional taxonomy", Research Policy, vol. 35, n. 2, pp. 289-308.

Netval (2007), "Il salto di qualità. Quinto rapporto annuale sulla valorizzazione della ricerca nelle università italiane", Netval, Crui, ProTon.

Nosella A., Grimaldi R. (2009), "University-level mechanisms supporting the creation of new companies : an analysis of Italian academic spin-offs", Technology Analysis \& Strategic Management, vol. 21, n. 6, pp. 679-698.

O'Shea, R. P., Allen, T. J., Chevalier, A. et Roche, F. (2005), "Entrepreneurial orientation, technology transfer and spinoff performance of U.S. universities", Research Policy, n. 34, n. 7, pp. 994 - 1009.

Pace, G. (2002), "Incubators as catalysts of academic spin-offs: evidence from the Israeli case-study", paper presented at the $42^{\text {nd }}$ European Regional Science Association Congress, Dortmund, August $27^{\text {th }}-31^{\text {st }}$.

Parry, M. et Russell, P., eds. (2000), "The planning, development and operation of science parks", UKSPA, Birmingham: The United Kingdom Science Park Association (UKSPA).

Pérez Pérez M., Sànchez A. M. (2003), "The development of university spin-offs: early dynamics of technology transfer and networking", Technovation, vol. 23, n. 10, pp. 823-831.

Piccaluga A., Balderi C. (2006), "Consistenza ed evoluzione delle imprese spin-off della ricerca pubblica in Italia", Laboratorio IN-SAT della Scuola Superiore Sant'Anna per Finlombarda S.p.A.

Powell W., Grodal S. (2005), "Networks of Innovators", in Fagerberg J., Mowery D. C., Nelson R.R., eds. (2005), “The Oxford Handbook of Innovation", Oxford, Oxford University Press.

Pirnay F., Surlemont B., Nlemvo F. (2003), “Toward a Typology of University Spin-offs”, Small Business Economics, vol. 21, n. 4, pp. 355-369.

Roberts, E. (1991), "High Stakes for High-Tech Entrepreneurs: Understanding Venture Capital Decision Making", Sloan Management Review, vol. 32, n. 2, pp. 9-20.

Rolfo, S. et Calabrese, G. (2006), "Concepts, measures and perspectives on innovation policy", Int. J. of Foresight and Innovation Policy, vol. 2, n. 3-4, pp. 247-264.

Rothaermel, F. T. et Thursby, M. (2005), "University-incubator firm knowledge flows: assessing their impact on incubator firm performance", Research Policy, vol. 34, n. 3, pp. 305-320.

Rowe, D. (2002) 'Science Parks in the United Kingdom Today and Tomorrow', APTE conference proceedings.

Salvador E. (2009), "Evolution of Italian universities'rules for spin-offs: the usefulness of formal regulations", Industry\&Higher Education, vol. 23, n. 6, pp. 445-462.

Salvador E. (2010), "Are science parks and incubators good "brand names" for spin-offs? The case-study of Turin", in Journal of Technology Transfer, ISSN 0892-9912 (Print) 1573-7047 (Online), DOI 10.1007/s10961-010-9152-0, forthcoming.

Sancin, P., ed. (1999), "R\&S, innovazione tecnologica e sviluppo del territorio: il ruolo dei parchi scientifici", Trieste, Area SciencePark.

Saxenian A. (1994), "Regional advantage: culture and competition in Silicon Valley and Route 128", Cambridge, MA, Harvard University Press.

Schwartz M. (2009), "Beyond incubation: an analysis of firm survival and exit dynamics in the post-graduation period", Journal of Technology Transfer, vol. 34, n. 4, pp. 403-421.

Schumpeter J. (1934), “The Theory of Economic Development”, Cambridge Mass., Harvard University Press. 
Shane S., Stuart T. (2002), "Organizational endowments and the performance of university start-ups", Management Science, vol. 48, n. 1, pp. 154-170.

Shane, S. (2004), "Academic Entrepreneurship. University Spinoffs and Wealth Creation", Cheltenham, UK, Edward Elgar.

Siegel D. S., Wright M., Lockett A. (2007), "The rise of entrepreneurial activity at universities: organizational and societal implications", Industrial and Corporate Change, vol. 16, n. 4, pp. 489-504.

Siegel, D. S., Westhead, P. et Wright, M. (2003), "Assessing the impact of science parks on the research productivity of firms: exploratory evidence from the United Kingdom”, International Journal of Industrial Organization, vol. 21, n. 9, pp. 1335-1369.

Sofouli E., Vonortas N. S. (2007), "S\&T parks and business incubators in middle-sized countries: the case of Greece", Journal of Technology Transfer, vol. 32, n. 5, pp. 525-544.

Squicciarini M. (2008), "Science Parks'tenants versus out-of-park firms: who innovates more? A duration model”, Journal of Technology Transfer, vol. 33, n. 1, pp. 45-71.

Stankiewicz R. (1994), "Spin-off companies from universities", Science and Public Policy, vol. 21, n. 2, pp. 99-107.

Steffensen M., Rogers E. M., Speakman K. (1999), "Spin-offs from research centers at a research university", Journal of Business Venturing, vol. 15, n. 1, pp. 93-111.

Wessner C. W. (2009), ed., "Understanding research, science and technology parks: global best practice: report of a symposium", National Research Council of the National Academies, Washington DC, The National Academies Press, downloaded from http://www.nap.edu/catalog/12546.html

Westhead P., Storey D. J. (1995), "Links between higher education institutions and high technology firms", Omega, vol. 23, n. 4, pp. 345-360.

Witt U., Zellner C. (2007), "Knowledge-based entrepreneurship: the organizational side of technology commercialization", in Malerba F., Brusoni S., eds., (2007), "Perspectives on Innovation", Cambridge, Cambridge University Press.

Wright M., Clarysse B., Lockett A., Binks M. (2006), "Venture capital and university spin-outs", Research Policy, vol. 35, n. 4, pp. 481-501.

Wright, M., Clarysse, B., Mustar, P. et Lockett, A. (2007), “Academic Entrepreneurship in Europe”, Cheltenham UK, Edward Elgar.

Wright, M., Vohora, A. et Lockett, A. (2004), "The Formation of High-Tech University Spinouts: The Role of Joint Ventures and Venture Capital Investors", Journal of Technology Transfer, vol. 29, n. 3-4, pp. 287-310.

Yang C.-H., Motohashi K., Chen J.-R. (2009), "Are new technology-based firms located on science parks really more innovative? Evidence from Taiwan", Research Policy, vol. 38, n. 1, pp. 77-85.

Zahra S. A., Van de Velde E., Larraneta B. (2007), "Knowledge conversion capability and the performance of corporate and university spin-offs", Industrial and Corporate Change, vol. 16, n. 4, pp. 569-608.

Zhang J. (2009), "The performance of university spin-offs: an exploratory analysis using venture capital data", Journal of Technology Transfer, vol. 34, n. 3, pp. 255-285. 